\title{
Glutamate Receptor Ionotropic, NMDA 2A
}

National Cancer Institute

\section{Source}

National Cancer Institute. Glutamate Receptor lonotropic, NMDA 2A. NCI Thesaurus.

Code C98149.

Glutamate receptor ionotropic, NMDA 2A (1464 aa, 165 kDa) is encoded by the human GRIN2A gene. This protein is involved in the modulation of ion transport. 